\title{
DIFFERENCES INTO HT AND HTO CONCENTRATIONS IN AIR INTO THE WESTERN MEDITERRANEAN BASIN AND CONTINENTAL EUROPE AND SAFETY RELATED ISSUES
}

\author{
P.Castro, ${ }^{1}$ M.Velarde, ${ }^{2}$ J.Ardao, ${ }^{3}$ J.M.Perlado ${ }^{2}$, \\ L.Sedano ${ }^{I}$ \\ 1 EURATOM-CIEMAT Association \\ LNF Fusion National Laboratory, BBTU \\ 28040-Madrid, Spain \\ paloma.castro@ciemat.es;

\section{ETSII Nuclear Fusion Institute: DENIM, Madrid, Spain, martavmayol@gmail.com; josemanuel.perlado@denim.upm.es}

\begin{abstract}
Real time Tritium concentrations in air in two chemical forms, HT and HTO, coming from an ITER-like fusion reactor as source were coupled the European Centre Medium Range Weather Forecast (ECMWF) numerical model with the Lagrangian Atmospheric-particle dispersion model FLEXPART. This tool was analyzed in nominal tritium discharge operational reference and selected incidental conditions affecting the Western Mediterranean Basin during 45 days during summer 2010 together with surface "wind observations" or weather data based in real hourly observations of wind direction and velocity providing a real approximation of the tritium behavior after the release to the atmosphere from a fusion reactor. From comparison with NORMTRI - a code using climatologically sequences as input - over the same area, the real time results have demonstrated an apparent overestimation of the corresponding climatologically sequence of Tritium concentrations in air outputs, at several distances from the reactor. For this purpose two development patterns were established. The first one was following a cyclonic circulation over the Mediterranean Sea and the second one was based on the plume delivered over the Interior of the Iberian Peninsula and Continental Europe by another stabilized circulation corresponding to a High Pressure System. One of the important remaining activities defined then, was the qualification tool. In order to validate the model of ECMWF/FLEXPART we have developed of a new complete data base of tritium concentrations for the months from November 2010 to March 2011 and defined a new set of four patterns of HT transport in air, in each case using real boundary conditions: stationary to the North, stationary to the South, fast and very fast displacement. Finally the differences corresponding to those four early patterns (each one in assessments 1 and 2) has been analyzed in terms of the tuning of safety related issues and taking into account the primary phase of tritium modeling, from its discharge to the atmosphere to the deposition on the ground, will affect to the complete tritium
\end{abstract}

\author{
3. AEMET, Environmental Applications Service, \\ 28040 Madrid, Spain \\ jardao@aemet.es
}

environmental pathway altering the chronic dose by absorption, reemission and ingestion both from elemental tritium, HT and from the oxide of tritium, HTO.

Keywords-component; Atmospheric Tritium; Tritiated cloud, HT and HTO wet depositions.

\section{INTRODUCTION. EDES UNDER PENTA LEVEL 3} REQUIREMENTS FOR PRECUATIONARY MEASURES TAKEN FROM NORMTRI. ECMWF/FLEXPART MODEL REQUIRED IN THE PRIMARY PHASE.

In order to validate ECMWF/FLEXPART model it has been determined, in routine conditions of ITER the Most Exposed Individual (MEI) remains under defined values in the PENTA protocol as precautionary measurements.

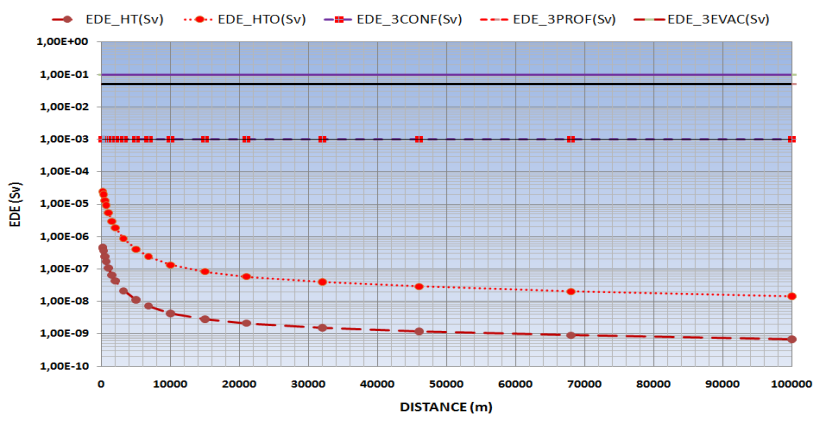

Figure 1. NORMTRI executed for ITER reactor HT/HTO effluents at 30 level in routine, has given EDE by contribution of exposure pathways (percentage of inhalation, percentage of ingestion; and percentage of inhalation due reemission. 
In reference [1] Effective Dose (EDE) from a NORMTRI study case was shown at all radial distances the precautionary "Plan of Emergency at Tarragona (PENTA) measurements for confinement were not required, due doses are under the regulatory PENTA limits.

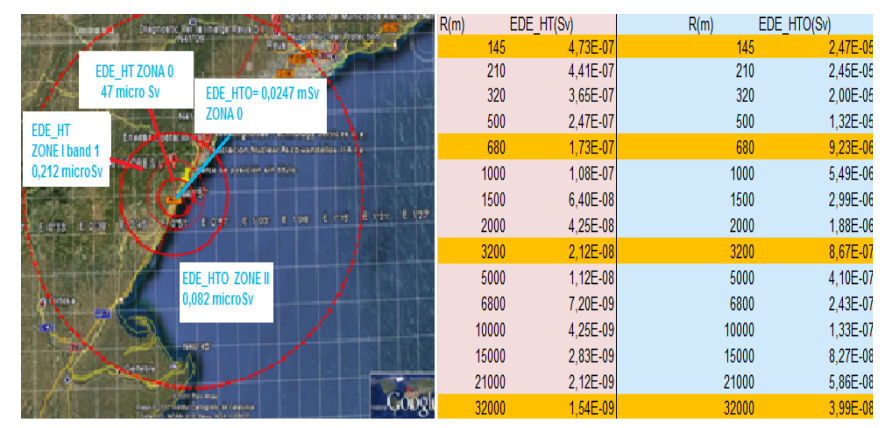

Figure 2. Some examples of EDE(Sv) for zones 0, I and II. [1,2]

Some examples of EDES (Sv) for zones 0,I and II $[1,2]$ in the closest $30 \mathrm{~km}$ to the reactor were already presented. When we made the validation of the model ECMWF/FLEXPART with a new complete data base of tritium concentrations for November 2010 to March 2011 we used special air patterns for tritium transport from source at Vandellós to the atmosphere low levels in the boundary layer in form of "tritiated clouds" if elemental HT or tritiated water. The aim of this paper is to define the new tritium cloud patterns and their consequences. For this purpuse some particular examples will be presented and later compared. Concerning source term we assume major concentration activity of the tritiated species should be in the very low levels. Therefore we have selected 10,30 and 60 meters for obtaining ECMWF/FLEXPART products of the emission release of tritium (when in continuous displacement in the boundary layer) [1]. The source term is placed in Vandellós, this is considered the point of release in routine. Fictitious exaggerated tritium sources of about $2.7 \mathrm{mg}$ of tritium per event-day $(\sim 25 \mathrm{Ci} /$ event-d) in HT form (e.g. emitted $3.65 \mathrm{mg}$ of HT) or $0.27 \mathrm{mg}(\sim 2.5 \mathrm{Ci} /$ eventd) of tritium per event-day in HTO (e.g. emitted: $1.8 \mathrm{mg}$ of HTO) [4]. The dispersion of atmospheric tritium can be very different, as a function of the water vapor tritiated clouds development and movement (stratified or convective, horizontal or with vertical ascendant or descendent air currents).

\section{EXAMPLE OF MEDITERRANEAN CASE 17 MARCH 2011}

\section{A. Real time evolution of HT by ECMWF/FLEXPART products}

The transport of elemental tritium gas from source to the environment and by the atmosphere has been presented in four steps and different places,from Tortosa Canyon to the South of Balearic Islands, during the 17th and 18th of March 2011 (figure 3) with the corresponding real time evolution of HT by ECMWF/FLEXPART products [5].

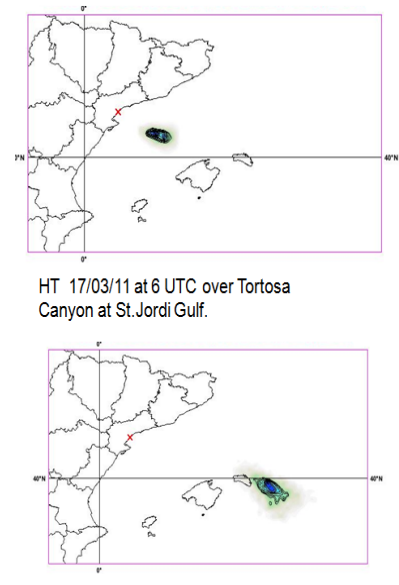

HT 17/03/11 at 18 UTC over the East of Menorca

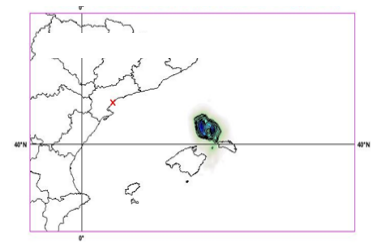

HT $17 / 03 / 11$ at 12 UTC over the North of Menorca

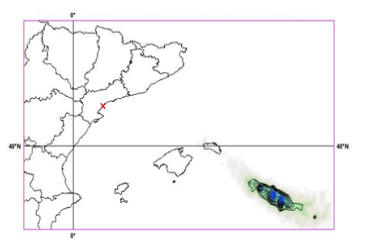

HT 18/03/11 at 00 UTC over South of the Balearic Islands and North of Algiers .
Figure 3. Daily evolution of HT cloud/plume at $10 \mathrm{~m}$ from reactor over the Mediterranean Sea. During 24 hours, the displacement of elemental tritium gas in four steps and different places from Tortosa Canyon to the South of Balearic Islands.

Forecast HT clouds valid on the 18th of March 2011 by midnight can be observed at the South of the Balearic Islands (and North of Algiers). However in order to make comparison we just look for behaviour in PENTA Zones and around 120$130 \mathrm{~km}$

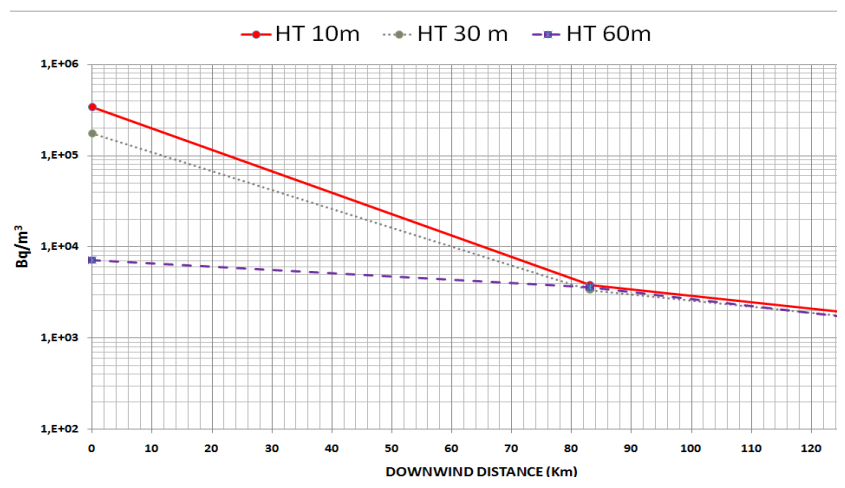

Figure 4. Variable atmospheric HT cloud/plume transport at three levels at $10 \mathrm{~m}, 30 \mathrm{~m}$ and $60 \mathrm{~m}$ from reactor to $130 \mathrm{~km}$ downwind distance. Differences in the first $80 \mathrm{Km}$. Values over $1 \mathrm{E}+5$ in the first $10 \mathrm{Km}$ for the two lower levels.

Variable atmospheric HT cloud/plume transport is different at the 3 levels at $10 \mathrm{~m}, 30 \mathrm{~m}$ and $60 \mathrm{~m}$ in the first $80 \mathrm{Km}$. Concentration values are over $1 \mathrm{E}+5$ just in the first $10 \mathrm{Km}$ for the two lower levels. For downwind distances major than 80 $\mathrm{km}$ a lineal decrease of concentrations is observed in a similar fashion for all levels. 


\section{B. HT and HTO forecast evolution in short range, from 3 to 24 hours}

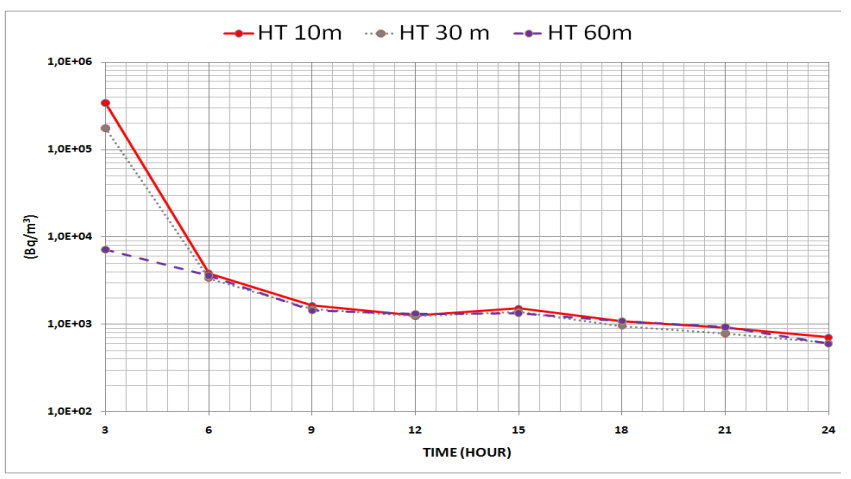

Figure 5. Short range forecast evolution of atmospheric HT cloud/plume at $10 \mathrm{~m}, 30 \mathrm{~m}$ and 60 over the Mediterranean Sea. After 6 hours no significant differences forecasted between levels.

Initial evolution shows major concentrations for HT at $10 \mathrm{~m}$ (red line). The similarities in the short range forecast evolution of atmospheric HT cloud/plume at $10 \mathrm{~m}, 30 \mathrm{~m}$ and $60 \mathrm{~m}$ after 6 hours over the Mediterranean Sea is clear in the figure 5 . Slightly logical differences for HT at $60 \mathrm{~m}$ (minor in the afternoon and by night).

Making systematic analysis of the complete data base, it leads to the requirement of stabilizing a set of threshold in the key parameters (mainly concentration and wind velocity) that allows representing a set of patterns in both sceneries: Mediterranean and Interior. Even they are slightly different, we introduce just Mediterranean Sea cloud Patterns of HT and finally we present another example for the interior case in order to compare them.

\section{MEditerRaneAn PATterns OF HT}

After the analysis of the 6 month data base of real time ECMWF/FLEXPART tritium dispersion products it can be defined a set of patters coming from a particular source term in a selected plant location. We are looking for both the selection of tritiated cloud patterns in our data base and later a "possible" optimization of the Plant location.

\section{A. Stationary Plume to North}

After the analysis of the 6 month data base of real time ECMWF/FLEXPART tritium dispersion products it can be defined a conceptual stationary plume, when it can be transported downwind from source to less than around $100 \mathrm{~km}$. When clouds are moving to the North of Vandellós, the atmospheric tritium can diminish 3 orders of magnitude, e.g. from $1 \mathrm{E}+6$ to $1 \mathrm{E}+3\left(\mathrm{~Bq} / \mathrm{m}^{3}\right)$. This reduction can be chaotic. Wind speed corresponds to light (from the South) winds (e.g. velocity under $1,5 \mathrm{~m} / \mathrm{s}$ or around $5 \mathrm{~km} / \mathrm{h}$ )

\section{B. Stationary Plume to South}

A stationary (or quasi-stationary) plume when moving to the South of Vandellós concentrations of atmospheric tritium can decrease by 3 orders of magnitude, e.g. from $1 \mathrm{E}+6$ to $1 \mathrm{E}+3$ $\left(\mathrm{Bq} / \mathrm{m}^{3}\right)$. This reduction can be linear in Sea and chaotic by the interior (due orography e.g. Karman vortex, and other effects). Wind speed corresponds to light (from the North) winds (e.g. velocity under $5,5 \mathrm{~m} / \mathrm{s}$ ). In the figure 6 variables HT cloud/plume at $10 \mathrm{~m}, 30 \mathrm{~m}$ and $60 \mathrm{~m}$ from reactor to around 50 $\mathrm{km}$ downwind distance and their corresponding lineal concentrations, in $\mathrm{Bq} / \mathrm{m}^{3}$ can be observed over the Mediterranean Sea.

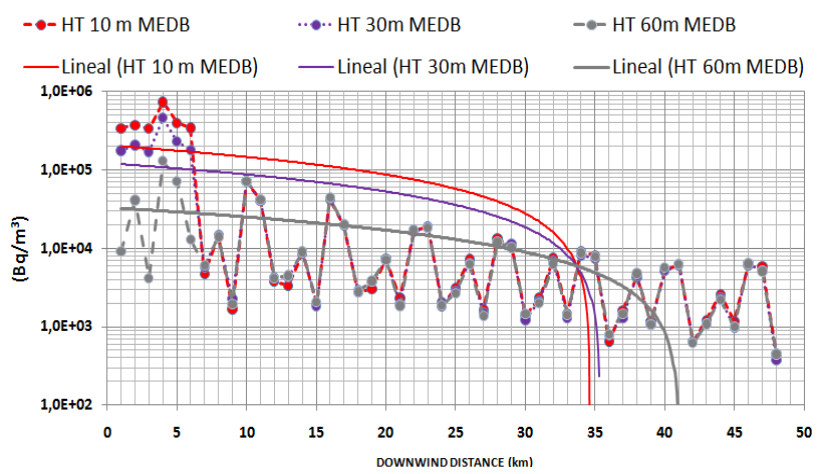

Figure 6. Variable HT cloud/plume at $10 \mathrm{~m}, 30 \mathrm{~m}$ and $60 \mathrm{~m}$ from reactor to 50 $\mathrm{km}$ downwind distance and their corresponding lineal concentrations

\section{Fast displacement Plume}

Fast displacement plume when moving from Vandellós concentrations of atmospheric tritium can decrease even 4 orders of magnitude, e.g from $1 \mathrm{E}+6$ to $1 \mathrm{E}+2\left(\mathrm{~Bq} / \mathrm{m}^{3}\right)$. This reduction can be quasi-linear in Sea (and "flow dependant" by the interior). Wind speed corresponds to moderate winds (e.g. velocity under around $15 \mathrm{~m} / \mathrm{s}$ ) therefore a larger displacement is foreseen. In the figure 7 variables HT cloud/plume at $10 \mathrm{~m}$, $30 \mathrm{~m}$ and $60 \mathrm{~m}$ from reactor to around $130 \mathrm{~km}$ downwind distance and their corresponding lineal concentrations, in $\mathrm{Bq} / \mathrm{m} 3$ can be observed over the Mediterranean Sea.

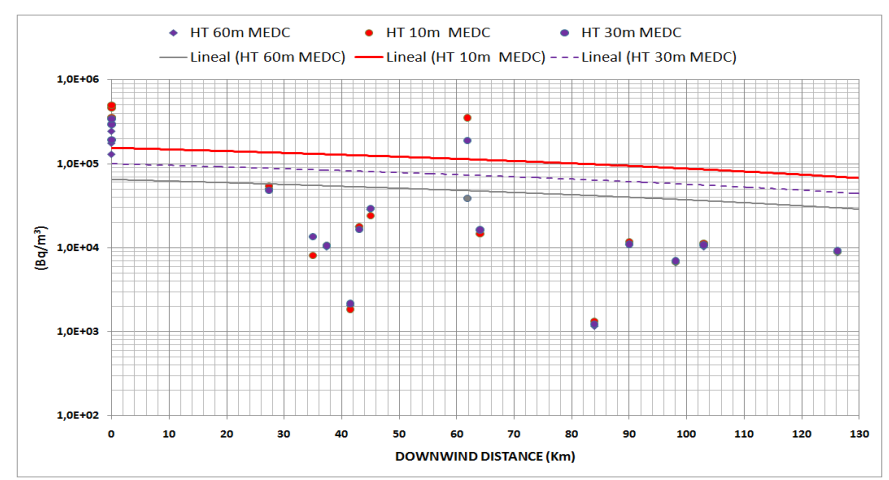

Figure 7. HT cloud/plume at $10 \mathrm{~m}, 30 \mathrm{~m}$ and $60 \mathrm{~m}$ from reactor to $130 \mathrm{~km}$ downwind distance and their corresponding lineal concentrations, around $1 \mathrm{E}+5 \mathrm{~Bq} / \mathrm{m}^{3}$ 
TABLE I. PROPOSED DESIGN TRITIUM IN AIR PATTERS IN MEDITERRANEUM

\begin{tabular}{|c|c|c|c|c|}
\hline Patterm & $\begin{array}{l}\text { Transport plume } \\
\text { distance }(\mathrm{Km})\end{array}$ & $\begin{array}{l}\text { Magnitud order } \\
\text { range } \\
\mathrm{HT}\left(\mathrm{Bq} / \mathrm{m}^{3}\right)\end{array}$ & $\begin{array}{l}\text { Tendency HT } \\
\text { reduction }\end{array}$ & $\begin{array}{l}\text { Observed } 10 \mathrm{~m} \\
\text { wind }(\mathrm{km} / \mathrm{h})\end{array}$ \\
\hline $\begin{array}{l}\text { A-Stationary } \\
\text { Plume to North }\end{array}$ & $\begin{array}{l}0<R<100 \mathrm{~km} \\
\text { Local to mesoscale }\end{array}$ & $6-3$ & $\begin{array}{l}\text { Caotic fashion } \\
\text { ruduction }\end{array}$ & $\begin{array}{l}\text { CALM OR VERY } \\
\text { LIGHT } \\
0<V<5 \mathrm{~km} / \mathrm{h}\end{array}$ \\
\hline $\begin{array}{l}\text { B-Stationary } \\
\text { plume to the } \\
\text { South }\end{array}$ & $\begin{array}{l}0<R<100 \mathrm{Km} \\
\text { Mesocale transport }\end{array}$ & $3-6$ & $\begin{array}{l}\text { No Reduction ( } \& \\
\text { orographic } \\
\text { effects ljust in } \\
\text { coast) }\end{array}$ & $\begin{array}{l}\text { LIGHT } \\
0<\mathrm{v}<20 \mathrm{~km} / \mathrm{h}\end{array}$ \\
\hline $\begin{array}{l}\text { C-Fast } \\
\text { displacement } \\
\text { plume+Vortex by } \\
\text { orography }\end{array}$ & $\begin{array}{l}100<R<200 \mathrm{Km} \\
\text { Largetransport } \\
\text { distance (in } \\
\text { mesoescale) }\end{array}$ & $6-2$ & $\begin{array}{l}\text { Quasi lineal } \\
\text { reduction }\end{array}$ & $\begin{array}{l}\text { MODERATE } \\
20<v<50 \mathrm{Km} / \mathrm{h}\end{array}$ \\
\hline $\begin{array}{l}\text { D-Very fast } \\
\text { displacement } \\
\text { Plume }\end{array}$ & $\begin{array}{l}\mathrm{R}>240 \mathrm{Km} \\
\text { Very Large } \\
\text { transport distance } \\
\text { (to synoptic) }\end{array}$ & $6-2$ & $\begin{array}{l}\text { Continuos } \\
\text { reduction }\end{array}$ & $\begin{array}{l}\text { STRONG } \\
50<v<100 \\
\mathrm{Km} / \mathrm{h}\end{array}$ \\
\hline
\end{tabular}

\section{Very Fast displacement Plume}

Very Fast displacement plume when moving from Vandellós Plant concentrations of atmospheric tritium can diminish even 4 orders of magnitude, e.g. from $1 \mathrm{E}+6$ to $1 \mathrm{E}+2\left(\mathrm{~Bq} / \mathrm{m}^{3}\right)$. This continues reduction corresponds to the strong winds (at least greater than $25 \mathrm{mph}$ or $15 \mathrm{~m} / \mathrm{s}$ )

Table I summarized proposed defined tritium in air defined patterns in the Mediterranean Sea. Other different tuned features may be observed in the interior. To have the overview of all possibilities, in the next points, we present a particularization of two cases, one Mediterranean Sea (corresponding to the $17^{\text {th }}$ of March 2011) and the second one over the interior and corresponding to the $15^{\text {th }}$ of March). Finally we can compare both scenarios and assessments for conclusion on differences.

\section{EXAMPLE OF INTERIOR CASE 15 MARCH 2011 WITH PRECIPITATION}

\section{A. Real time evolution of HT by ECMWF/FLEXPART products}

The transport of elemental tritium gas from source to the environment and by the atmosphere has been presented in four steps and different places, from Vandellós to the interior of Aragón and in displacement to the North and again coming back to the coast, during the 15th and 16th of March 2011 (figure 3) with the corresponding real time evolution of HT by ECMWF/FLEXPART products

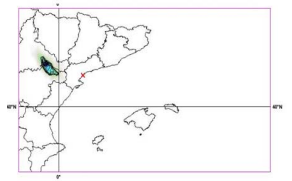

HT 15/03/11 at 6 UTC over interior of Aragón

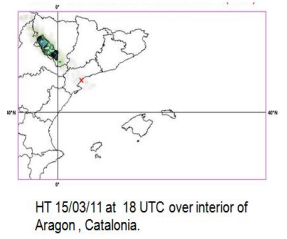

Figure 8. Daily evolution of HT cloud/plume at $10 \mathrm{~m}$ from reactor over the Interior of the Iberian Peninsula. During 24 hours, the displacement of elemental tritium gas in four steps and different places from Aragón back to Catalonian coast.

Forecast HT clouds valid on the 16th of March 2011 by midnight can be observed in PENTA Zones and around 120 $\mathrm{km}$.

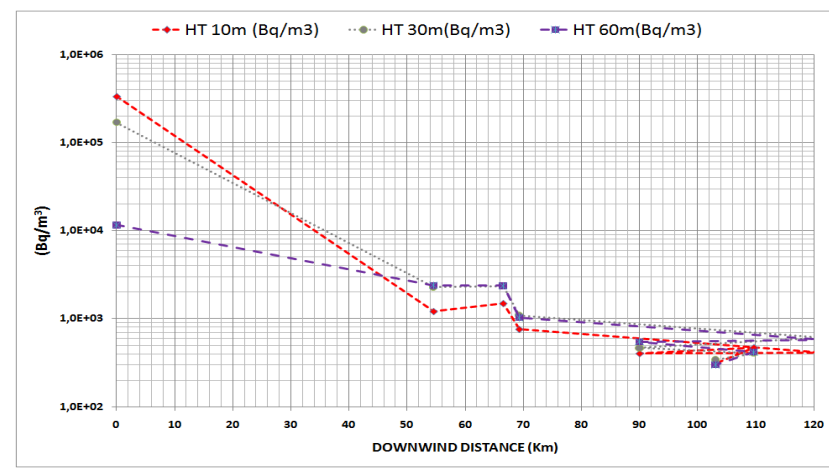

Figure 9. Caotic/different atmospheric HT cloud/plume transport at three levels at $10 \mathrm{~m}, 30 \mathrm{~m}$ and $60 \mathrm{~m}$ from reactor to $120 \mathrm{~km}$ downwind distance. Differences in levels at all distances. Values over $1 \mathrm{E}+5$ in the first $20 \mathrm{Km}$

Different atmospheric HT cloud/plume transport at 3 levels in the boundary layer from source reactor to $120 \mathrm{~km}$ downwind distance. Differences in levels at all distances. Values over $1 \mathrm{E}+5$ in the first $20 \mathrm{Km}$ for the 2 lower levels.

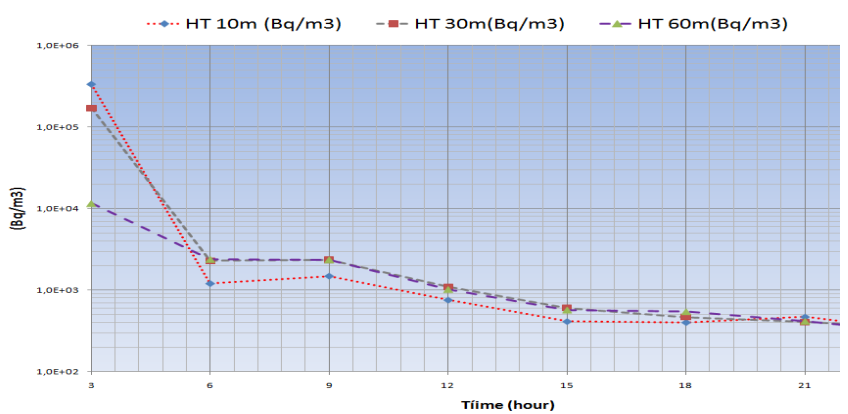

Figure 10. Short range forecast evolution of atmospheric HT cloud/plume at $10 \mathrm{~m}, 30 \mathrm{~m}$ and $60 \mathrm{~m}$ from reactor to more than 120 downwind distance over the Continent. After 6 hours significant differences between levels.

Variable atmospheric HT cloud/plume transport is very diffrent at the 3 levels at $10 \mathrm{~m}, 30 \mathrm{~m}$ and $60 \mathrm{~m}$ in the $120 \mathrm{~km}$ range from source. Concentration values are over $1 \mathrm{E}+5$ just in the first 3-4 hours and around first $10 \mathrm{~km}$ for the two lower levels. No lineal decrease but caotic decrease of HT of concentrations is observed for all levels. (Fig. 9 and 10) 


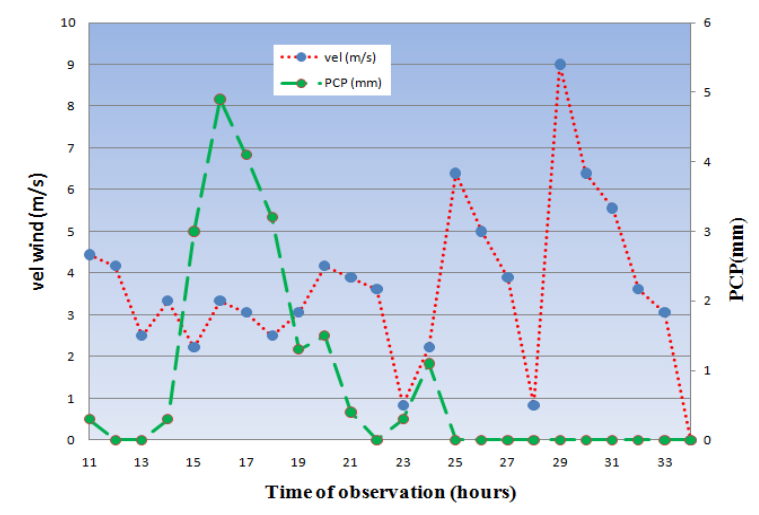

Figure 11. Variations of the wind velocity $(\mathrm{m} / \mathrm{s})$ during precipitation $(\mathrm{mm})$ observed in the $15^{\text {th }}$ of March 2011 (and first hour of the $14^{\text {th }}$ ) and after.

Original data taken from AEMET (www.aemet.es ) atTortosa.
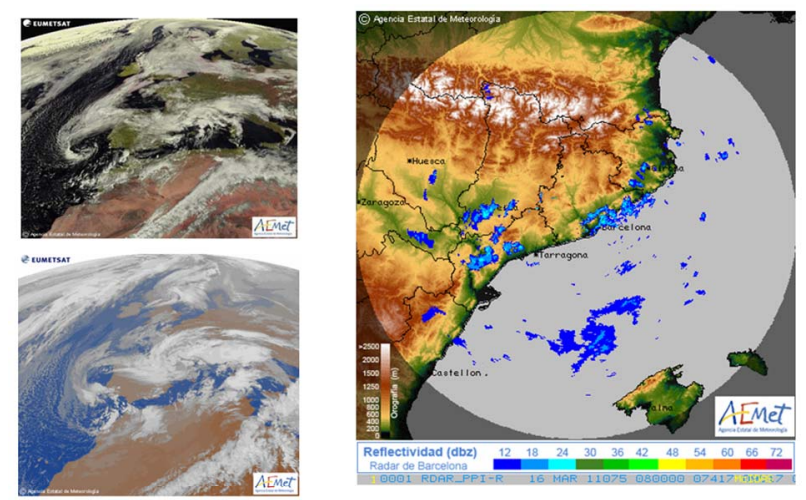

Figure 12. Remote sensing observations in March the $15^{\text {th }}$. In particular VIS and IR Meteosat Second Generation (MSG) images and reflectivity observed in the regional $\mathrm{BCN}$ radar along coast and interior of Catalunya and Aragón

The remote sensing observations are (both for satellite and radar) presented in the Figure 12. Reduction of concentration and transport of clouds (observed e.g. at $10 \mathrm{~m}$ in figures 9 and 10) in the interior of Catalonia corresponds to the area of precipitation (green dashed line) and wind reduction (red dotted line) forecasted for afternoon (see Figure 11). Radar reflectivity values corresponding to PPI on 16 March can be interpreted as an overestimation of surface PCP $(\mathrm{mm})$ however its clear rainfall can lead to a cleaner atmosphere (concerning minor concentrations of HT in air). In satellite IR and VIS imagery at leas two low centers can be detected as follows: one over the Gulf of Cadiz and the second one over Catalonia and South of France and the baroclinic band [14] is already extended up to the North of Africa. Radar reflectivity values corresponding to PPI on 16 March can be interpreted as an overestimation of surface PCP $(\mathrm{mm})$ however its clear rainfall can lead to a cleaner atmosphere (concerning minor concentrations of HT in air.
IV. COMPARISON OF HT AND HTO OVER MEDITERRANEUM AND CONTINENTAL EUROPE

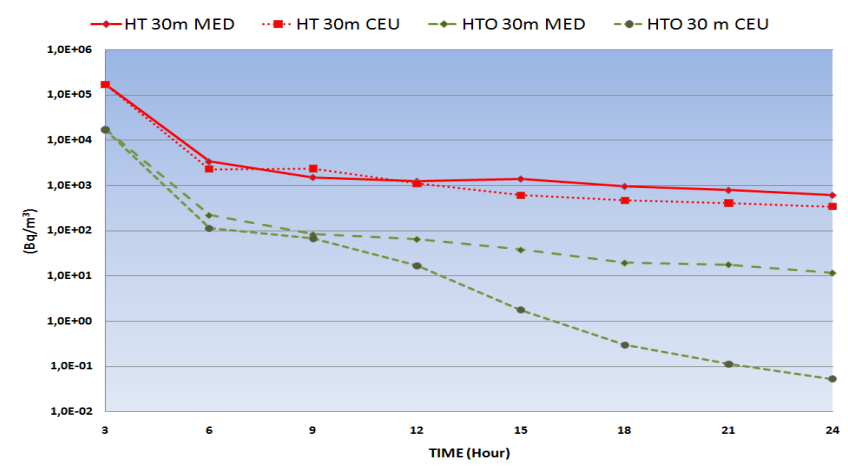

Figure 13. Early evolution comparison HT (red lines) and HTO (green lines) at $30 \mathrm{~m}$ from Mediterranean Sea to Continental Europe

The early evolution comparison HT (red lines) and HTO (green lines) at $30 \mathrm{~m}$ from Mediterranean Sea to Continental Europe is shown in figure 13. For both HT and HTO clouds over Mediterranean Basin and Continental Europe (CEUR) there are a lineal decreasing evolution. Forecast HT values are similar over Mediterranean Sea and CEUR (except by 9 UTC). On the contrary HTO values are minor in CEUR, may be due daily thermal oscillation; in other words an increasing in temperature (at noon and early afternoon) implies a decreasing HTO concentration (And also with HT).

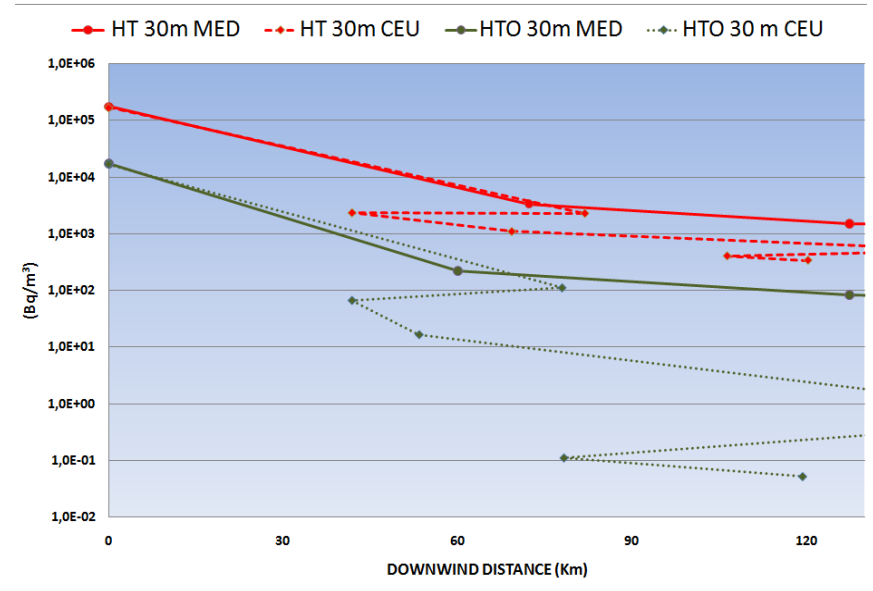

Figure 14. Transport of HT (red lines) and HTO (green lines) at $30 \mathrm{~m}$ from Mediterranean Sea and Continental Europe from reactor localisation to downwind distances of $130 \mathrm{~km}$. HT is reduced caotically at Continental Europe. Major values of HTO in CEUR for distances minor than $70 \mathrm{~km}$

There are differences in the HT and HTO transport detected in the figure 14. In this case HTO is major in the Continental Europe than in the Mediterranean Sea in the first $70 \mathrm{Km}$. This particular exception may be due local effects as e.g. the lee orographic diffusion and/or stagnant by Pyrenees. 


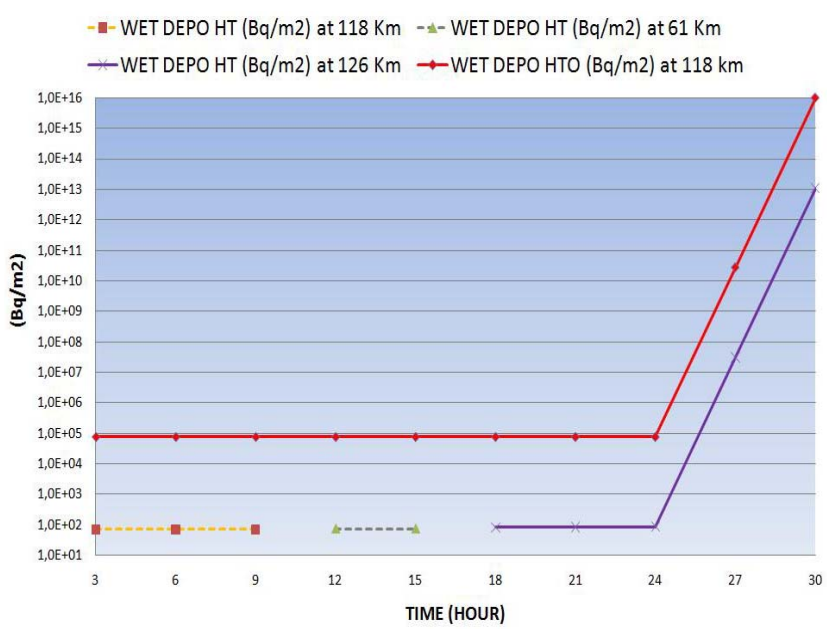

Figure 15. Corresponding evolution with the increase of wet deposition on the $15^{\text {th }}$ of March, due cleaning effect of the PCP both in Wet deposition of HT and HTO from 18 to 30 hours increase. At $118 \mathrm{~km}$ the Wet deposition of HTO (red) is greater than HT Wet deposition

Also precipitation (observed by remote sensing) in March 15th play a role in cleaning air (and there is an increase of wet depositions forecast by the ECMWF/FLEXPART modeling system (Figure 15). Both Wet deposition of HT and HTO from 18 to 30 hours increase. At $118 \mathrm{~km}$ the Wet deposition of HTO (red) forecast is 3 orders of magnitude greater than HT. This can be associated to PCP, In particular visible and infrared Meteosat Second Generation (MSG) images and reflectivity observed in the regional BCN radar (figures 11 and 12) along coast and interior of Catalonia and Aragón at least at downwind distances around $120 \mathrm{~km}$. In this area, maximum value of wet deposition $1,113 \mathrm{E}+13\left(\mathrm{~Bq} / \mathrm{m}^{2}\right)$ has been detected when observed maximum convective rainfall was $18 \mathrm{~mm}$.

\section{CONCLUSSIONS}

In routine conditions of ITER the Most Exposed Individual (MEI) remains under the defined values into the SP protocol PENTA as precautionary measurements. Therefore, in level 3, EDEs remain under the threshold values for a possible confinement in the exclusion zone (Zone 0). Further refinement may be based on Primary Phase outputs of ECMWF/FLEXPART.

For primary phase several patterns have been determined for tritium Clouds over the Mediterranean Basin (MED) and have been compared with other cases over continental Europe (CEUR).

ECMWF/FLEXPART HT and HTO clouds in air shown forecast concentrations with one order of magnitude of difference due source term original HT and HTO daily concentrations, correspondent to 1 gram of HT/year (and 0,1 gram HTO/year).

For both HT and HTO clouds over Mediterranean Basin and CEUR there are a lineal decreasing evolution (in all levels).
HT and HTO clouds over Mediterranean show a major transport by influence in diffusion, advection and/or convection. In the CEUR case the transport is limited to distances of less than $180 \mathrm{Km}$ and it may be strongly influenced by the SP orography (Iberian System, Ebro Valley) and precipitations.

In any case variations of safety issues related due atmospheric thermal profile (e.g. at the low troposphere). Again expected real time MEI remains under controlled thresholds.

\section{REFERENCES}

[1] P.Castro, M.Velarde, J.Ardao, J.M.Perlado and L.Sedano, "Validation of Real Time Dispersion of Tritium in ITER reactor over the Western Mediterranean Basin in different assesments", ICENES 2011 Proceedings.

[2] Plan of Nuclear Emergency Exterior to Ascó and Vandellós (Tarragona). BOE 173, 21 Jul 2006.

[3] .Persson, F. Grazzini "User Guide to ECMWF forecast products. Version 4.0, 14-march 2007.

[4] A. Stohl, C et al. Technical note: The Lagrangian particle dispersion model FLEXPART version 6.2. Norwegian Institute of Air Research, Kjeller, Norway. Organization, Vienna, Austria. Manuscript version from 21 April 2005.

[5] P. Castro, M. Velarde, J. Ardao, J. M. Perlado, L. Sedano "Consequences of different meteorological scenarios in the environmental impact assessment of tritium release" 2P01-09," Book of Abstracts 9th International Conference on Tritium Science and Technology. TRITIUM 2010, October 24-29, 2010 Nara, Japan, FSD (2010).

[6] D.Arnold, A.Vargas, M. Montero, A. Dvorzhak, P.Seibert. "Comparison of the dispersion model in RODOS-LX1 and MM5-V3.7FLEXPART(V6.2). A case study for the nuclear power plant of Almaraz (Spain)". Croatian Meteorological Journal. HARMO 12, Vol.43, pp485490, 2008 (ISSN: 1330-0083)

[7] EU Scientific Seminar 2007 "Emerging Issues on Tritium and Low Energy Beta Emitters". Proceedings of a scientific seminar held in Luxembourg on 13 November 2007 Working Party on Research Implications on Health and Safety Standards of the Article 31 Group of experts.

[8] M.Velarde, J. M. Perlado. "Tritium Dose Assessments under ITER accidental/normal Operational conditions for the European Candidate Site of Vandellós (Spain). April 2003. Contract EISS-Vandellós.

[9] W. Raskob. NORMTRI, A Computer Program for assessing the Off_Site Consequences from Air-Borne Releases of Tritium during Normal Operation of Nuclear Facilities. Report KfK-5364. (1994).

[10] W. Raskob, M. Velarde, J.M. Perlado, "Tritium Tritium Dose Assessments with Regulatory and Advanced Computer Models For The Potential European ITER Site Vandellós (Spain)", Fusion Science and Technology (2005).

[11] Claudio Rizzello, Fabio Borgognoni, Tonio Pinna, Silvano Tosti,"Review of tritium confinement and atmosphere detritiation system in hot cells complex" Fusion Engineering and Design, Volume 85, Issue 1, January 2010, Pages 58-63.

[12] Tritium release and dose consequences in Canada 2006. Part of tritium Studies Project. INFO-0793. Dec 2009. Canadá Nuclear Regulator. Canada Nuclear Safety Commision.

[13] DOE Handbook, "Tritium Handling and Safe Storage". US. Department of Energy. Washington, D.C. 20585 (2008)

[14] J. Houghton et al. Physics of Planetary atmosphere. Spanish coordinated version by C,García Legaz,INM ISBN:83-7837-065-X. Madrid, (1992) 